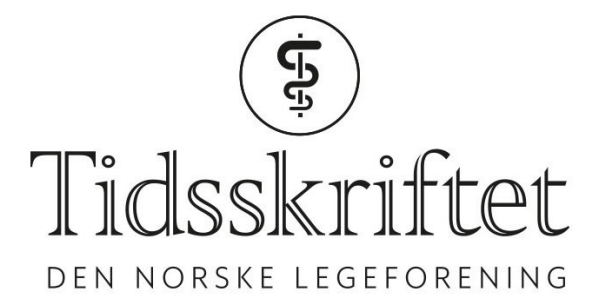

\title{
En xenotransplantasjon i 1882
}

TIDLIGERE I TIDSSKRIFTET

JULIE DIDRIKSEN

Tidsskriftet

På 18oo-tallet ble det gjort en del fors $ø \mathrm{k}$ på transplantasjoner fra dyr til mennesker. Under følger en sak vi hadde på trykk i nr. 14/1883, da vi fortsatt het Tidsskrift for Praktisk Medicin. En kvinne hadde gjennomgått en angivelig vellykket muskeltransplantasjon fra en hund (Tidsskr Prakt Med 1883; 3: 222-3).

\section{En lykket Muskeltransplantation fra en Hund til et Menneske}

I Archiv für klin. Chirurg. XXVIII, 3, p. 562, 1882 findes en Beskrivelse af et heldigt Experiment med at transplantere Biceps fra en Hund til et Menneske, hvoraf her leveres et Uddrag efter Schm. Jahrb. 1883.3 H. P. 259.

En 36aarig Frøken havde en Svulst i den øvre Halvdel af den høire Biceps, som indtog næsten hele Musklens Tykkelse. Den var af Størrelse som et Par Børnehænder og viste sig ved Exstirpationen at være et Fibrosarcom. Hvor Svulsten sad, var der kun tilbage en liden Bundt af Musklen saa tyk som en Blyant, den var normal; nedenfor var normalt Muskelvæv, ovenfor Senen. Denne smale Muskelstreng blev nu præpareret løs fra Svulstmassen og blev i Forbindelse med Enderne af Biceps, V. bracchialis og n. cutaneus bracchii medius var omgivne af Svulsten, men kunde dog konserveres; den til Biceps forløbende Gren af n. musculocutaneus derimod maatte skjæres over. Paa den indre glatte Smitflade anlagdes 3 Katgutligaturer. Det borttagne Stykke Muskel udgjorde hele den øvre Halvdel med Undtagelse af den lille omtalte Bundt. I dette Defekt blev nu indsat et rigelig stort Stykke af en Hunds biceps femoris. Det skede med stor Hurtighet og med Undgaaelse af enhver Kontusion af den transplanterte Muskel. Muskelfladerne og Muskelenderne forenedes omhyggelig med Suturer. Operationen gjordes med Karbolantisepsis uden Spray. Det indsatte Stykke Muskel var ikke ubetydelig tykkere end Tversnittet af den exstirperede Biceps og dannede nedad en tydelig Svulst. Den løspreparerede Hud blev nu syet sammen; 6 Drains blev indlagt og Listers Bandage; Armen fixeredes i spidsvinklet Bøining i Albuen til Thorax. Operationen foretoges den 16de Febr. Den 25de Februar udtømte der sig af det indre Drainrør et ganske løst Muskelstykke, som svarede til hele Længden og omtrent 1/5 af Tykkelsen af den transplanterte Muskel. Ellers var Tilhelingen fuldstændig. Fra d. 28de Marts anvendtes daglig Elektricitet.

En Undersøgelse d. 19de Mai viste et normalt Forhold mod begge Slags Elektricitet. Kun det $\emptyset$ verste Punkt for Elektriseringen af N. muskulocutaneus paa den indre Rand af Biceps paa den opererte Side manglede. De aktive Bevægelser var kraftfulde. Ved den aktive Flexion af Armen i Albueledet, som gik lige let for sig i proneret og supineret Stilling, følge man en 
Fremskydning af Biceps som ved en elektrisk Kontraktion. Der kunde derfor ikke være Tvivl, om at Musklen fungerte. Spørgsmaalet hvorledes Innervationen kunde foregaa, da dog Nerven maatte skjæres af, maa vel besvares saaledes, at den sandsynlig lededes fra det nedre bevarede Stykke af Biceps, som rimeligvis besad sin egen motoriske Nervegren.

Publisert: 5. mars 2019. Tidsskr Nor Legeforen. DOI: 10.4045/tidsskr.18.0938

(C) Tidsskrift for Den norske legeforening 2020. Lastet ned fra tidsskriftet.no 